\title{
Family Business Succession and Post Succession Performance: Evidence from Thai SMEs
}

\author{
Vanvisa Chaimahawong ${ }^{1} \&$ Atthapong Sakulsriprasert ${ }^{1}$ \\ ${ }^{1}$ Business Administration Division, Mahidol University International College, Thailand \\ Correspondence: Vanvisa Chaimahawong, Business Administration Division, Mahidol University International \\ College, Thailand. Tel: 660-2441-5090 Ext. 1727. E-mail: vanvisa.cha@mahidol.ac.th
}

Received: October 15, 2012 Accepted: November 1, 2012 Online Published: December 14, 2012

doi:10.5539/ijbm.v8n2p19

URL: http://dx.doi.org/10.5539/ijbm.v8n2p19

\begin{abstract}
This paper aims to study the key factors affecting the process of business succession and post succession of family firms in Thailand. The purpose of this research paper is to identify the level of impacts and classify into four determinants i.e. the personal factor, the intra-family relationship factors, the context factors, and the financial factors. The paper also aims to study the relationship between the four factors and the post succession performance of family firms in Thailand. The methods use to assess the level of impacts of the factors on succession process of family firms in Thailand is by using the method of Structural Equation Model (SEM). The results of the SEM are based from the sample size 374 family business owners across various industries in Thailand. Context factors and personal factors are the two factors that have the highest levels of impact on the effectiveness of the succession process in comparison to the financial factors and the intra-family relationship. The results from this research paper also indicate that the succession process and the post-succession performance are positively related with a high level of impact.
\end{abstract}

Keywords: family business, succession planning, strategy, incumbent, successor

\section{Introduction}

The study of family business has been of interest to researchers in the past few decades. A family-owned business can be defined as "a business managed with the intention to pursue the vision of the business held by a dominant coalition controlled by members of family", (Sharma, Chrisman, Pablo \& Chua, 2001). One of the most crucial research topics in the study of family business is "family business successions", which refers to the actions, events, and developments that affect the transfer of managerial control from one family member to another (Sharma, et.al, 2001).

According to Malinen (2001), family business has been acknowledged as a source of sustainable economic growth. It is notable that a large number of listed companies in Europe and Asia are still family-owned. The family has a major influence and control over the firm in terms of the business ownership and management control. From past studies on the topic of family business, scholars have suggested that approximately 30 percent of family firms survive into the second generation of family ownership (Kets de Vries, 1993) and roughly 16 percents survive further into the third generation (Morris, et. al, 1997). One the reasons for the low survival rate of family businesses is the problem of family business succession.

Thailand is one of the industrialized countries in Asia where economic growth is driven by family-owned firms. The study by Suehiro and Wailerdsak (2004), showed that the proportion of family- owned business that are listed on the Stock Exchange of Thailand has decreased from 48.2 percent in the year 1996 to 42.3 percent in the year 2000. By collecting data from the top 100 companies listed on the Stock Exchange of Thailand, Pongpaijit (2006) showed that out of the 100 companies ranked according to the total revenue earned, the number of family owned business had decreased from 57 companies in the year 2000 to 56 companies in the year 2004, and was further reduced to 38 companies in 2007. This showed that there is a low survival rate for family business in Thailand.

\section{Literature Review}

In this paper the authors provide classify the key determinants affecting the process of family business succession into four main categories, which are: personal factors, intra-family relationship factors, context 
factors and financial factors

Levinson (1971) and Kets de Vries (1988) discovered that the main problem in the succession process was due to the personal characteristics of both the potential successor and the incumbent. This may include having the necessary skills required to operate the business, the willingness of the successor to join the family business, and the preparation level that the potential successors have before joining the family business. Goldberg (1993) also concluded that the level of self confidence of the successors has a positive bearing on the effectiveness of the succession process; hence, the potential successor must possess high self-confidence and must have the managerial skills to run the business. If the potential successor is under-qualified due to a lack of necessary skills and poor preparation, the potential successor may then refuse the position offered by the incumbent, hence causing a breakdown in the succession process (Potts et. al, 2001; Le Breton-Miller et.al, 2004; Venter et al., 2005). According to Shama and Raos (2000), the level of interest of the potential successors toward the family business can also increase or decrease their willingness to commit to working for the family. If the potential successor is dissatisfied with the family business, the chances that he or she will take over the business from the incumbent will be reduced due to a decrease in the motivation to work for the business (Potts et al., 2001, Le Breton-Miller et al., 2004; and Venter et al., 2005). Cespedes \& Galford (2004) used the events at the Tiverton Media Corporation to show an example of a failure in the succession process because of lack of motivation and willingness to continue the family business.

Good preparation level is the key to the successful transfer of managerial power from the incumbent to the successor. Morris (1997) classifies the preparation level of the potential successor into the following factors which includes; the formal education level, training received from the incumbent, work experience (outside the firms), entry-level position, and the number of years working with the family business before the succession take place. Scholars also found a positive relationship between the preparation level that the potential successor has had and the effectiveness of the succession process. The higher the preparation level that the potential successor has, the higher the chance that he or she will take over the business after the incumbent steps down. (Le Breton-Miller et al., 2004).

Family tradition and the quality of the relationships between the family members also plays a major role in family business and how successful the business will be (Kepner, 1983; Lansberg, 1983). An effective succession process will occur if the successor feels that it is in the family tradition to continue on the family business (Morris, 1996; and Malinen, 2001; Lee, 2003). To make the potential successor feel welcomed and consequently willing to continue the family business, the quality of the relationships between the potential successors, the incumbents and other family members must be positive. If both the incumbent and the successor have a mutual understanding about the future of their family business, there will be less conflict among them; hence, a higher chance for an effective succession (Malinen, 2001; Miller et al., 2003; Venter et al., 2005). The quality of the relationship between the successor and other family members, such as siblings, is also considered to be important in the succession process (Brockhaus, 2004). A high level of competitiveness and conflict between siblings usually discourages the potential successor. Hence, hindering the succession process (Cespedes and Galford, 2004; Bruce and Picard, 2006).

Context factor is the factor associated with changes in the economic environment that has the effect on family business operation. In this research, context factors refer to the related aspects of the succession process that might prevent the succession from taking place. The economic environment can influence succession because of some contingency and uncertainty in the business environment. Changes in the business environment and market conditions can alter the future prospects of the family business. If changes in the market conditions increase the probability for business failure, then the incumbent is less likely to transfer the business to his or her potential successor. The uncertainty will create pressure for the incumbent to sell the firm (Carlock \& Ward, 2001; Cespedes \& Galford, 2004; and Venter et al., 2005). Moreover, the size of the business also matters. The larger the size of the firm, the higher the chance that the offspring will join the business. Therefore, the smaller the size, the higher the chance that the potential successor will leave the family business due to possibly unattractive monetary rewards (Venter et. al, 2005).

Financial factors play a vital role in preventing succession. The financial factors include the factors related to limitations in the company's financial resources in terms of the current tax burden and the cost of obtaining external financing. According to Malinen (2001), Taxation is the biggest problem in the family business succession process because of the difficulties in understanding the complicated legal regulations. Moreover, financing the succession is considered to be another problem in family business succession. By studying the family business succession process in Finland, Malinen (2001) found out that the incumbent usually did not want the children to suffer from financial difficulties after the succession. This created pressure on the incumbent to 
forgo a succession opportunity and sell the business.

Griffeth et. al (2006) defines the term "successful family business succession" or "successful management succession" as a continuous process whereby leadership and power is transferred from one family member to the next, while maintaining positive family relationships, and enabling the business to expand and prosper financially. However, the relationship between the succession and performance of the company in the post succession period is still unclear. Therefore, another objective of this paper is to also investigate the relationship between the key determinants of family business succession and the firm's performance after the succession period.

\section{Methodology}

Although there have been many studies focusing on family succession, very few of the studies in the area family business succession are qualitative based. Therefore, the objective of this study is to create a quantitative research paper by using the Structural Equation Model (SEM) to quantify the level of impact on each factor to the effectiveness of the family business succession. The advantage of using the SEM approach is to be able to simultaneously analyze the effect of both direct and indirect variables on the succession performance.

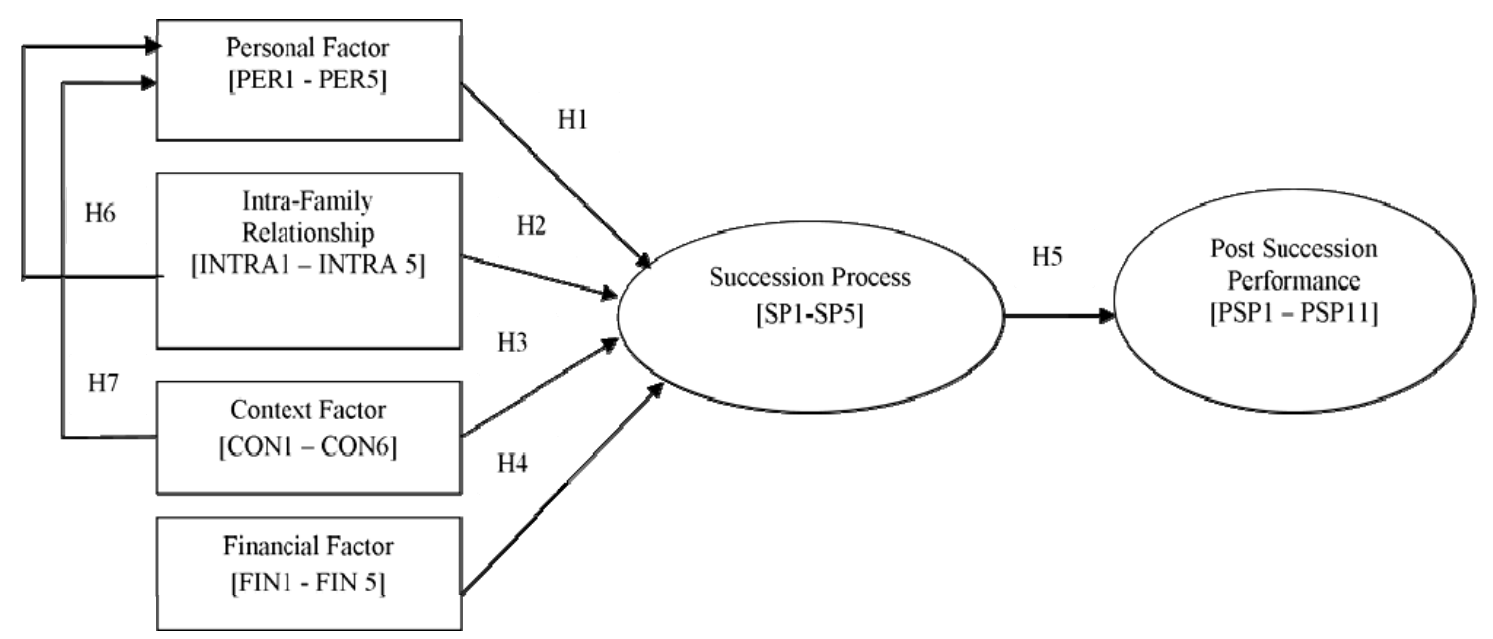

Figure 1. Proposed model for SEM testing

This research paper aims to examine the relationship between the pre-succession period, the effectiveness of the succession process and the post-succession performance of family firms in Thailand by using the four constructs namely: personal factor, intra-family relationship factor, context factor, and the financial factor to determine the overall effect.

From the conceptual model, the authors have come up with the following hypotheses:

H1: The character of the successor has an impact on the effectiveness of the succession process.

H2: The quality of the relationship between the family members has an impact on the effectiveness of the succession process.

H3: The business context and its environment have an impact on the effectiveness of the succession process.

H4: The financial factor has an impact on the effectiveness of the succession process.

H5: The succession process has an impact on the post-succession performance.

After testing hypothesises 1 to 5 , the authors also tested whether the context factor and the intra-family relationship factor will have any effect on the personal factor. Therefore, the authors have come up with the following hypothesis:

H6: The context factor is related positively to the personal factor.

H7: The intra-family relationship factor is positively related to the personal factor.

In order to obtain the level of impact of each factor on the succession process and to measure the post succession performance, the authors distributed 374 questionnaires to family business owners in Thailand. The 
questionnaire was divided into four parts (as shown in Appendix 1). The first part was concerned mainly with the respondent's background in terms of their position in the firm, the type of business they are engaged in, and their number of years of experience in their family firm. The second part of the questionnaire dealt with the pre-succession period by looking at the four factors: personal factor, intra-family relationship factor, context factor, and financial factor that may have had an impact on the succession process. The third part of the questionnaire was related to the succession process itself and the last part dealt with the post succession performance. With the exception of part one, each question was designed using the seven-point Likert scale ( $7=$ strongly agree, 1 = strongly disagree).

After all the data was collected, the authors will used Cronbach's alpha to perform the reliability analysis in order to test for the internal consistency of each of the constructs. Apart from using Cronbach's alpha to test for the fit index, the authors also tested each construct by using the convergent validity test as well as performing discriminant analysis to show that all the constructs provided sufficient evidence to conclude that each selected criteria was valid and could be used for the Structural Equation Model (SEM).

\section{Result and Discussion}

\subsection{Measurement Properties}

The reliability analysis was performed to test for the internal consistency of each construct. Table 1 show the result of Cronbach's alpha for the four constructs, which shows sufficient evidence of good reliability based on the criteria of 0.6 .

Table 1 . Construct reliability analysis

\begin{tabular}{llcc}
\hline \multicolumn{1}{c}{ Factor } & & $\mathrm{N}=$ Number of item & $\alpha=$ Cronbach's Alpha \\
\hline Personal Factor & PER1 - PER5 & 5 & 0.914 \\
Intra-Family Relationship & INT1 - INT5 & 5 & 0.879 \\
Context Factor & CON1- CON 6 & 6 & 0.880 \\
Financial Factor & FIN1- FIN 3 & 3 & 0.619 \\
Succession Process & SPR1- SPR5 & 5 & 0.914 \\
Post Succession Performance & PSP1- PSP 11 & 11 & 0.838
\end{tabular}

Before examining the structural model estimates, the authors also performed an evaluation of the items proposed for measurement of the latent variables. Table 2 indicates that each construct met all the criteria according to the goodness of fit indices of the convergent validity of $\chi^{2} / \mathrm{df}, \mathrm{NFI}$, NNFI, CFI, and RMSEA.

Table 2. Goodness of fit indices of the overall construct

\begin{tabular}{lcc}
\hline Factor & Fit Indices & Criteria \\
\hline$\chi^{2} / \mathrm{df}$ & 2.353 & Less than 3.00 \\
Norm Fit Index (NFI) & 0.958 & More than 0.90 \\
Non-Norm Fit Index (NNFI) & 0.962 & More than 0.90 \\
Comparative Fit Index (CFI) & 0.962 & More than 0.90 \\
Root Mean Square Error for Approximation (RMSEA) & 0.060 & Less than 0.08 \\
\hline
\end{tabular}

Table 3 also shows the test for construct reliability which was calculated for each construct. The standardized loading of all the constructs was higher than 0.6, supporting the reliability of scales. All loading factors are above 0.5 and statistically significant for $\mathrm{p}<0.05$. Hence, the result shows the evidence of convergent validity for the scale used in this study. 
Table 3. Construct measurement summary (standardized loading and t-value)

\begin{tabular}{|c|c|c|}
\hline Construct and Items & Standard Loading & t-Value \\
\hline \multicolumn{3}{|l|}{ Construct 1: Personal Factor } \\
\hline PSP 1 & 0.450 & \\
\hline PSP 2 & 0.538 & 6.083 \\
\hline PSP 3 & 0.866 & 7.399 \\
\hline PSP 4 & 0.906 & 7.462 \\
\hline PSP 5 & 0.636 & 6.605 \\
\hline \multicolumn{3}{|l|}{ Construct 2: Intra-Family relationship } \\
\hline INT 1 & 0.852 & \\
\hline INT 2 & 0.866 & 17.267 \\
\hline INT 3 & 0.790 & 15.091 \\
\hline INT 4 & 0.745 & 11.390 \\
\hline INT 5 & 0.708 & 12.904 \\
\hline \multicolumn{3}{|l|}{ Construct 3: Context Factor } \\
\hline $\mathrm{CON} 1$ & 0.703 & \\
\hline CON 2 & 0.704 & 10.650 \\
\hline $\mathrm{CON} 3$ & 0.689 & 10.429 \\
\hline $\mathrm{CON} 4$ & 0.816 & 12.234 \\
\hline CON 5 & 0.815 & 12.225 \\
\hline CON 6 & 0.726 & 10.963 \\
\hline \multicolumn{3}{|l|}{ Construct 4: Financial Factor } \\
\hline FIN 1 & 0.552 & \\
\hline FIN 2 & 0.815 & 7.149 \\
\hline FIN 3 & 0.549 & 6.414 \\
\hline \multicolumn{3}{|l|}{ Construct 5: Succession Process } \\
\hline SPR 1 & 0.863 & \\
\hline SPR 2 & 0.816 & 15.518 \\
\hline SPR 3 & 0.637 & 11.085 \\
\hline SPR 4 & 0.587 & 10.014 \\
\hline SPR 5 & 0.657 & 11.538 \\
\hline \multicolumn{3}{|c|}{ Construct 6: Post Succession Performance } \\
\hline PSP 1 & 0.742 & \\
\hline PSP 2 & 0.717 & 11.638 \\
\hline PSP 3 & 0.717 & 11.649 \\
\hline PSP 4 & 0.732 & 11.908 \\
\hline PSP 5 & 0.741 & 12.069 \\
\hline PSP 6 & 0.719 & 11.674 \\
\hline PSP 7 & 0.619 & 9.952 \\
\hline PSP 8 & 0.618 & 9.923 \\
\hline PSP9 & 0.724 & 11.774 \\
\hline PSP 10 & 0.703 & 11.396 \\
\hline PSP 11 & 0.710 & 11.528 \\
\hline
\end{tabular}


Apart from testing for convergent validity the authors also performed pair-wise discriminant tests for discrimination validity as shown in Table 4 . The highest difference between the fixed and the free chi-square is 217.05, whereas the lowest value of 5.20 is still higher than the minimum criteria of 3.84 (Farrell, 2010). Therefore, the results for pair-wise analysis have proven that the all the constructs in the questionnaire can be used for SEM.

Table 4. Discriminant validity assessment result (Pair wise)

\begin{tabular}{lcccc}
\hline \multicolumn{1}{c}{ Construct } & $\chi^{2}$ Fixed & $\chi^{2}$ Free & $\begin{array}{c}\chi^{2} \\
\text { Difference [d.f. =1] }\end{array}$ & $\begin{array}{c}\text { Significant at } \\
\text { p value }\end{array}$ \\
\hline Personal factor and intra family relationship & 76.946 & 68.670 & 8.28 & $<0.05$ \\
Personal Factor and context factor & 88.953 & 104.578 & 15.63 & $<0.05$ \\
Personal Factor and financial factor & 37.870 & 23.698 & 14.17 & $<0.05$ \\
Personal Factor and succession process & 69.035 & 63.832 & 5.20 & $<0.05$ \\
Personal Factor and post succession process & 222.450 & 368.045 & 145.60 & $<0.05$ \\
Intra-family Relationship and context factor & 109.473 & 128.486 & 19.01 & $<0.05$ \\
Intra-family relationship and financial factor & 77.646 & 71.250 & 6.40 & $<0.05$ \\
Intra-family relationship and succession process & 121.445 & 129.062 & 7.62 & $<0.05$ \\
Intra-family relationship and post succession process & 331.328 & 456.423 & 125.10 & $<0.05$ \\
Context Factor and financial factor & 106.361 & 97.882 & 8.48 & $<0.05$ \\
Context factor and succession process & 127.491 & 144.209 & 16.72 & $<0.05$ \\
Context factor and post succession process & 311.659 & 528.713 & 217.05 & $<0.05$ \\
Financial factor and succession process & 67.866 & 64.626 & 6.24 & $<0.05$ \\
Financial factor and post succession process & 289.235 & 420.280 & 131.05 & $<0.05$ \\
$\begin{array}{l}\text { Family succession process and post succession } \\
\text { process }\end{array}$ & 408.650 & 452.845 & 43.90 & $<0.05$ \\
\hline
\end{tabular}

\subsection{Descriptive Statistics}

The descriptive statistics of the findings are summarized in Table 5 below:

Table 5. Descriptive statistic

\begin{tabular}{ll}
\hline Form of Business & Sole Proprietorship 47.1 percent; Partnership 4.8 percent; Limited Partnership \\
& 20.1 percent; Company Limited 28.1 percent \\
Types of Business & Manufacturing 29.9 percent; Service 26.5; Retail 25.7; Wholesale 17.9 percent \\
Sale per year & $\begin{array}{l}0-30 \text { millions } 52.7 \text { percent; 31-50 million } 15.2 \text { percent; More than } 51 \text { million } \\
\text { 32.2 percent }\end{array}$ \\
Years in Family Business & $\begin{array}{l}0-5 \text { years } 55 \text { percent; } 5-10 \text { years } 22.4 \text { percent; } 10 \text { to } 15 \text { years } 8.7 \text { percent; More } \\
\text { than } 15 \text { years 13.9 percent }\end{array}$ \\
\hline
\end{tabular}

From the 374 sets of questionnaires, it was found that the majority of family business firms that were surveyed are in the form of sole proprietorship. Sole proprietorship accounted for (47.1 percent), followed by limited companies (28.1 percent), limited partnerships (20.1 percent) and other partnerships (4.8 percent). The annual sales range of the respondents fall within the range of from 0 to 30 million baht per year, which indicates that most of respondents are small or medium sized enterprises. The majority of respondent have been engaged in their family business for less than five years and only 13.9 percent have been working with their family business for more than 15 years. 


\subsection{Model and Hypothesis Test}

The overall fit statistics indicate that the acceptable level of fit of the SEM Model as the model has passed all the criteria of the goodness of fit test according to Table 6.

Table 6. Goodness of fit test

\begin{tabular}{lcc}
\hline Items & Fit Indices & Criteria \\
\hline Normed Fit Index (NFI) & .924 & $>0.90$ \\
Non-Normed Fit Index (NNFI) & .947 & $>0.90$ \\
Comparative Fit Index (CFI) & .951 & $>0.90$ \\
Root Mean Square Error of Approximation (RMSEA) & .063 & $<0.08$ \\
\hline
\end{tabular}

Having tested the measurement model concerning the constructs of family business succession as well as testing for the overall fit of the Structural Equation Model, the next step was to link between each construct according the proposed hypothesis. Table 7 shows the standardized estimates of the relationship between each construct under the proposed hypothesis.

Table 7. Test of proposed relationship in the model

\begin{tabular}{lccc}
\hline Path & Coefficient & t- value & Result \\
\hline H1: Personal Factor $\rightarrow$ Succession Process & .469 & 4.012 & Accept \\
H2: Intra-Family Relationship $\rightarrow$ Succession Process & .279 & 5.293 & Accept \\
H3: Context Factor $\rightarrow$ Succession Process & .512 & 5.509 & Accept \\
H4: Financial Factor $\rightarrow$ Succession Process & .199 & 2.911 & Accept \\
H5: Succession Process $\rightarrow$ Post Succession Performance & .506 & 8.461 & Accept \\
H6: Intra-Family Relationship $\rightarrow$ Personal Factor & .118 & 2.902 & Accept \\
H7: Context Factor $\rightarrow$ Personal Factor & .398 & 4.919 & Accept \\
\hline
\end{tabular}

With the confidence interval of 95 percent, all the hypothesized relationships are found to have statistical significance. Personal Factor has the highest impact on the succession process in family business with the impact level of 0.469 , followed by the context factor, intra-family relationship and the financial factor which have coefficients of $0.512,0.279$, and 0.199 respectively. The results of the test hypothesis also show that there is a positive relationship between the succession process and the post-succession performance with the coefficient level of 0.506 . This indicates that there is a positive relationship between the succession process and the post-succession performance. Therefore how successful the firm will be after the succession strongly depends on how the well the succession process was organized and structured.

Apart from testing the relationship of each factor in the succession process and the post- succession performance, the authors also tested whether the intra-family relationship and the context factor will have an impact on the willingness of the successor to continue the family business (represented by $\mathrm{H6}$ and H7). The results portray a positive relationship between both factors and the personal factor. The relationship between the intra-family relationship and the personal factor has the coefficient of 0.118 , which is considered to be fairly weak compared to the coefficient of 0.398 that represents the relationship between the context factor and personal factor. Hence it can be concluded that the willingness for the successor to continue the family business depends on how well the successor understands the business context or the industry that the family business operates in.

\section{Conclusion and Recommendations}

In order to ensure that a family business in Thailand can survive through different generations, it is crucial to be able to identify the key factors that will affect the succession process. By using SEM this paper has successfully identified and determined the level of impact that each of four different factors has on the succession process. The results indicate that context factors and personal factors are the two constructs that have the highest levels of impact on the effectiveness of the success process. In comparison, the financial factors and the intra-family 
relationship factors have lesser impact. The results also indicate that the succession process and the post-succession performance are positively related with a high level of impact. Moreover, the authors also find out that the business context and the quality of the relationship between the family and the successor was also positively related to the personal factor; noting that the personal factor refers to the willingness of the successor to accept the position and then continue the family business.

From the results that are presented in this paper, it can be summarized that the authors have accomplished the objectives of the study. Apart from achieving satisfactory results, the study also made both theoretical and practical contribution to the study of family business in Thailand. In regard to the theoretical contribution, the authors have introduced the concept of using SEM to test the level of impact of factors in the succession process. The research paper also extended the body of knowledge for scholars in Thailand. Other scholars may want to continue the research on the topic of family business succession. For practical contributions, applying the result of this research would be beneficial to family firms who want to create effective succession plans. This research can be used as a guideline for both the incumbent and the successor in order to simplify the transition process and to prevent failures in family business succession.

\section{Limitations and Directions for Future Research}

Although the research has uncovered some beneficial findings in the study of family business succession, there are still some limitations to the studies that must be considered. Firstly, the paper only focused on the study of family firms in Thailand. Therefore, in order to make the study more general and applicable to various countries, future research should use different location settings to test the hypothesizes. Secondly, the research provided a quantitative result. Therefore, future researchers can use another approach and other methods of collecting data in order to provide a qualitative perspective to the problems regarding the succession process. Thirdly, the research paper is an example of cross-sectional research which only captures the data at a particular period of time. Therefore, future researchers should also employ other methods to study the succession process.

\section{References}

Birley, S. (1986). Succession in the Family: The inheritor's view. Journal of Small Business Management, July, 26-43.

Breton Miller, I. L., Miller, D., \& Steier, L. P. (2004). Toward an integrative model of effective FOB succession. Entrepreneurship Theory and Practice, 28(4), 305-328. http://dx.doi/10.1111/j.1540-6520.2004.00047.x

Brockhaus, R. H. (2004). Family business succession: suggestions for future research. Family Business Review, 17, 165-77. http://dx.doi.org/10.1111/j.1741-6248.2004.00011.x

Bruce, D., \& Picard, D. (2006). Making succession a success: perspective from a resource and knowledge-based View of Family Firms. Family Business Review, 14, 37-46. http://dx.doi/10.1111/j.1540-627X.2006.00171.x

Carlock, R. S., \& Aronoff, C. E. (2001). Strategic planning for the family business: Parallel planning to unite the family and business. Palgrave Macmillan.

Cespedes, F. V., \& Galford, R. M. (2004). Succession and failure. Harvard Business School Case Study, June.

Chua, J. H., Chrisman, J. J., \& Sharma, P. (1999). Defining the Family Business by Behavior. Entrepreneurship Theory and Practice, 23(4), 19-39.

Farrell, A. M. (2010). Insufficient discriminant validity: A comment on Bove, Pervan, Beatty, and Shiu (2009). Journal of Business Research, 63(3), 324-327. http://dx.doi.org/10.1016/j.jbusres.2009.05.003

Goldberg, S. D., \& Wooldrige, B. (1993). Self-confidence and managerial autonomy: Successor characteristics critical to succession in family firms. Family Business Review, 6, 55-73. http://dx.doi.org/10.1111/j.1741-6248.1993.00055.x

Kepner, E. (1983). The Family and the Firm: A co-evolutionary Perspective. Organizational Dynamics, 12(1), 57-70. http://dx.doi.org/10.1016/0090-2616(83)90027-X

Kets de Vries, M. F. R. (1988). The Dark Side of CEO Succession. Harvard Business Review, January-February, $56-60$.

Langsberg, I. (1983). Managing human resources in family firms. Organizational Dynamics, 12, 39-46. http://dx.doi.org/10.1016/0090-2616(83)90025-6

Lee, K. S., Lim, G. H., \& Lim, W. S. (2003). Family Business Succession: Appropriation Risk and Choice of 
Successors. Academy of Management Review, 28(4), 657-66.

Levinson, H. (1971). Conflicts that Plague Family Business. Harvard Business Review, 49(2), 90-98.

Malinen, P. (2001). Like father like son? Small family business succession problems in Finland. Enterprise and innovation management studies, 2(3), 195-204. http://dx.doi.org/10.1080/14632440110105053

Miller, D., Steier, L., \& Le Breton-Miller, I. (2003). Lost in time: intergenerational succession, change, and failure in family business. Journal of Business Venturing, 18(4), 513-31. http://dx.doi.org/10.1016/S0883-9026(03)00058-2

Morris, M. H., Williams, R. O., Allen, J. A., \& Avila, R. A. (1997). Correlates of success in family business transitions. Journal of Business Venturing, 12(5), 385-401. http://dx.doi.org/10.1016/S0883-9026(97)00010-4

Pongpaijit, P. (2006). Thai Capital. Mathichon Press, Bangkok, Thailand.

Potts, T. L., Schoen, J. E., Loeb, M. E., \& Hulme, F. S. (2001). Effective retirement for family business owner-managers: perspectives of financial planners, Part II. Journal of Financial Planning-Dever, 14(7), 86-97.

Sharma, P., \& Rao, A. S. (2000). Successor attributes in Indian and Canadian family firms: A comparative study. Family Business Review, 13(4), 313-330. http://dx.doi.org/10.1111/j.1741-6248.2000.00313.x

Sharma, P., Chrisman, J. J., Pablo, A. L., \& Chua, J. H. (2001). Determinants of initial satisfaction with the succession process in family firms: A conceptual model. Entrepreneurship Theory and Practice, 25(3), 17-36.

Suehiro, A., \& Wailerdsak, N. (2004), Family business in Thailand: its management, governance, and future challenges. ASEAN Economic Bulletin, 21(1), 81-93. http://dx.doi.org/10.1355/AE21-1E

Venter, E., Boshoff, C., \& Maas, G. (2005). The influence of successor - related factors on the succession process in small and medium - sized family businesses. Family Business Review, 18(4), 283-303. http://dx.doi.org/10.1111/j.1741-6248.2005.00049

\section{Appendix}

Appendix 1. Multi-item scale measures

Personal Factor

I am a bond to my family business.

PER 1

I have enough knowledge to continue my family business.

PER 2

I activity wants to engage and operate my family business.

PER 3

I am willing to continue my family business.

PER 4

My family business is an interesting business to continue.

PER 5

Intra-Family relationship

There is high level of trust within my family.

INT 1

There is high level of unity within my family.

INT 2

My family's members have high level of trust on me to pursue the family business.

INT 3

My family's members believe that I have the willingness to continue the family business. INT 4

There is no conflict within my family.

INT 5

Context Factor

I have a comprehensive understanding about my competitors' competitiveness.

CON 1

I have a comprehensive understanding of the business contexts that my family business operates in.

CON 2

I have a comprehensive understanding of the technologies that are important my business.

$\mathrm{CON} 3$

I have enough legal knowledge and understanding regarding to the rules and regulations that are

CON 4 important to my family business.

I have a comprehensive understanding of my target market.

CON 5

I have a comprehensive understanding of the business cycle and changes that are important to my family business.

CON 6 


\section{$\underline{\text { Financial Factor }}$}

The level of debt in the family business is considered to be at the appropriate level.

The level of cash flow required for the daily operation is at the appropriate level.

FIN 2

There is an appropriate process in my family firm to handle taxation problems.

FIN 3

\section{$\underline{\text { Succession Process }}$}

I have been formally assigned in advanced from the incumbent to continue the business.

There is a consent decision by my family members for me to continue my family business.

The incumbent has created effective succession plan to ease the transition process.

SPR 3

The incumbent has given me the autonomy to operate business.

SPR 4

I am well prepared to take over my family business

SPR 5

\section{Post Succession Performance}

After the succession process, the business has gain higher revenue.

After the succession process, the business has gain higher profit.

After the succession process, I have efficiently managed my employees.

PSP 3

After the succession process, the overall operation in my firms is more systematic.

After the succession process, I am able to create higher satisfaction level for my old client.

PSP 5

After the succession process, I am able to create higher satisfaction level for my new client

PSP 6

After the succession process, the company has implemented and used new technologies.

After the succession process, my employees have developed and acquire new skills.

PSP 8

After the succession process, my employees have become more skilled full.

PSP 9

After the succession process, the working environment in my company has improved.

PSP 10

After the succession process, I have gain more knowledge in operating my family business. 